\title{
Correction to: A mobile one-lead ECG device incorporated in a symptom-driven remote arrhythmia monitoring program. The first 5,982 Hartwacht ECGs
}

\section{J. L. Selder · L. Breukel · S. Blok · A. C. van Rossum · I. I. Tulevski · C. P. Allaart}

Published online: 23 January 2019

(c) The Author(s) 2019

\section{Correction to:}

\section{Neth Heart J 2018}

https://doi.org/10.1007/s12471-018-1203-4

Unfortunately the original version of this article did not reflect that J.L. Selder and L. Breukel contributed equally to the study.

Open Access This article is distributed under the terms of the Creative Commons Attribution 4.0 International License (http://creativecommons.org/licenses/by/4.0/), which permits unrestricted use, distribution, and reproduction in any medium, provided you give appropriate credit to the original author(s) and the source, provide a link to the Creative Commons license, and indicate if changes were made.

\author{
J. L. Selder $(\bowtie) \cdot$ A. C. van Rossum · C. P. Allaart \\ Amsterdam UMC, location VUMC, Amsterdam, The \\ Netherlands \\ j.selder@vumc.nl \\ L. Breukel \\ Onze Lieve Vrouwe Hospital, Amsterdam, The Netherlands \\ S. Blok · I. I. Tulevski \\ Cardiology Center Netherlands, Amsterdam, The \\ Netherlands
}

